\title{
Coccinellid Funa Associated with Pulse Crop-ecosystems from Rayalseema Region of Andhra Pradesh
}

\author{
T. Vasista*, M. S. V. Chalam, K. V. Hariprasad and G. Mohan Naidu
}

\author{
Acharya N. G. Ranga Agricultural University, Department of Entomology, S. V. Agricultural \\ College, Tirupati, 517502, Chittoor District (A.P.), India
}

*Corresponding author

\section{A B S T R A C T}

\section{Keywords}

Coccinellids,

Pulses,

Composition of

Coccinellids

\section{Article Info}

Accepted:

10 July 2020

Available Online:

10 August 2020
Studies were conducted to identify the predatory coccinellid beetle fauna associated with pulse crop ecosystems from Rayalaseema region of Andhra Pradesh. The beetles were collected by sweep netting and hand picking. Male and female genitalia, colouration, characters of elytra, mandibles and antenna were studied for accurate identification of the species. Ten species of coccinellids viz., Cheliomenes sexmaculata (Fabricius), Coccinella transversalis Fabricius, Coccinella septumpunctata Linnaeus, Illeis cincta (Fabricius), Harmonia octomaculata (Fabricius), Brumoides suturalis (Fabricius), Micraspis discolor (Fabricius), Scymnus nubulis Mulsant Jauravia dorsalis (Weise) and Pseudospidimerus trinotatus Thunberg were reported from pulse crop ecosystems in Rayalseema region of Andhra Pradesh. The above species were identified and described and the species composition was worked out. Among the predatory coccinellid species studied, $M$. sexmaculata $(41.00 \%$ of total coccinellids) ranked first in abundance followed by $C$. transversalis (28.55\% of total coccinellids), while $H$. octomaculata ranked last in abundance $(0.49 \%$ of total coccinellids). An illustrated key along with diagnostic taxonomic characters were provided for easy identification of the coccinellids associated with pulse crop eco-systems from Rayalseema region of Andhra Pradesh.

\section{Introduction}

Coccinellids belong to the order Coleoptera, suborder Polyphaga, super-family Cucujoidea, the family Coccenellidae and are commonly called as ladybird beetles, lady birds, lady bugs. Many taxonomic works on this important predacious family recognize six subfamilies within family Coccinellidae viz., Chilocorinae, Coccinellinae, Coccidulinae, Skymninae, Sticholotidinae and
Epilachininae, of these one subfamily Epilachininae is phytophagous and the rest are predaceous in nature (Sasaji, 1968). Vanderberg (2000) has provided a check list of 6000 species in 370 genera, where as Slipinski and Tomaszewska, 2005 has reported 6000 species of coccinellids in 490 genera occurring worldwide. Coccineliids are of great economic importance due to their predacious activity against soft bodied insects viz., aphids, scales, mealy bugs, leafhoppers, 
planthoppers, thrips, insect eggs, nymphs of various insects and phytophagous mites. In India 261 known predaceous coccinellid species belonging to 57 genera were reported (Omkar and Pervez, 2004). Coccinellids are oval to hemispherical in shape with clavate antennae, securiform maxillary palpi, pseudotrimerous tarsi and are often brightly coloured with red, orange (or) yellow shades. Due to their predatory nature, these beetles are considered as beneficial insects and are being employed as efficient biological control agents against different insect pests. Some of the best examples in utilization of coccinellids in biological control programmes include Rodolia cardinalis (Mulsant) against Iceria purchasi Maskell, Cryptolaemus montrouzieri Mulsant against Maconellisoccus hirusutus (Green) and Planococcus citri (Risso) etc (Kundoo and Khan, 2017). Composition of predatory Coccinellids varies widely among various crop ecosystems and so is their predatory potential on various hosts. Because of their greater economic importance many authors (Pajani and Verma 1985, Omkar and Pervez, 2004, Joshi and Sharma 2008) stressed the need of studying the indigenous coccinellid fauna. Coccinellid groups has been studied by several workers in India but all these studies pertains to a broad treatment of Indian Coccinellidae as a whole rather than giving importance to coccinellid fauna occurring crop ecosystem wise. However, no taxonomic studies were carried out in Rayalseema region of Andhra Pradesh to study the coccinellid fauna occurring in pulses crop ecosystems. Native coccinellids are considered as most important biological control agents in pulse crop ecosystems effectively controlling various pests like aphids, thrips, leafhoppers, whiteflies etc (Megha et al., 2015). Up to date key for identification of commonly available species of Coccinellids in Pulse crop ecosystems of Chittoor district are also not available. Hence the present studies were conducted to identify the native coccinellid fauna present in the pulse crop ecosystems of Rayalaseema region of Andhra Pradesh.

\section{Materials and Methods}

Coccinellid specimens were collected from predominant pulse crop ecosystems viz., black gram, green gram, red gram and cow pea of Chittor district in Rayalaseema Region of Andhra Pradesh. Sweep netting technique with the help of an insect collection net and hand collection methods were used to collect the coccinellid beetles. The collected beetles were killed with the help of cotton swab dipped in ethyl acetate. The dead specimens were dried in a hot air oven at $45-50^{\circ} \mathrm{C}$ for 56 hours and later stored in glass vials with labels. The labeling was given based on the crop on which collection was made and date of collection. The oven dried beetles were mounted singly on white thick cardboard triangular points. The mounting facilitates study of characters of head, thorax, abdomen, antenna, mouthparts etc from all the desired angles, which are very useful for taxonomic identification and description of coccinelllids. The abdomen of male and female beetles was detached, digested with 10 per cent $\mathrm{KOH}$ for overnight and the genitalia (Male and Female) were dissected as per the standard procedure (Poorani, 2002). The dissected genital parts (male and female), were studied with a research microscope for identification and drawings of genital parts. In addition to the genital parts, colouration, characters of elytra, mandibles, antenna etc were also studied for quick and accurate identification.

\section{Results and Discussion}

During the present studies, ten species of Coccinellids viz., Cheliomenes sexmaculata (Fabricius), Coccinella transversalis Fabricius, Coccinella septumpunctata Linnaeus, Illeis cincta (Fabricius), Harmonia 
octomaculata (Fabricius), Brumoides suturalis (Fabricius), Micraspis discolor (Fabricius), Scymnus nubulis Mulsant, Jauravia dorsalis (Weise) and Pseudospidimerus trinotatus Thunberg were reported from pulse crop ecosystems in Rayalseema region of Andhra Pradesh (Table 1). The most important taxonomic and morphological characters of the studies species were provided here under for easy identification.

\section{Cheilomenes sexmaculata (Fabricius) (Fig.1-4 and Plate 1 A)}

Beetles medium to large sized, elongate and oval in shape. Females generally larger than males. Colour variable, creamy orange to bright orange. Head pale yellow to yellowish, with a triangular black marking at middle of frons. Pronotum is yellow to orange with black markings. Scutellum black, elytra having black zigzag markings. The commissural line of elytra is black. Antennae 11 segmented, clavate. Elytra sparsely punctate. Legs having pseudotrimerous tarsi and tarsal segments densely hairy and ends with a pair of claws. Sipho strongly curved at base and thread like apically. The siphonal capsule well developed, inner processes rounded and external processes pointed. Tegmen with broad long median lobe. Spermatheca short, stout and curved; in ventral view spermatheca is kidney shaped.

\section{Coccinella transversalis Fabricius (Fig.5-8 and Plate 1 B)}

Oval beetles, strongly convex dorsally. Females generally larger than males. Colouration variable; dark yellow, creamy orange, pale yellow or brick red colour. Head black with yellow spots, antennae dark brown; eyes black; pronotum black; scutellum black. Elytra with black markings, commissural line black. Antenna 11 segmented, last segment enlarged and rounded. Elytra sparsely punctuate. Legs pseudotrimerous and end with a pair of claws. Tegmen with a Y shaped median lobe which is as long as lateral lobes. Sipho short and curved at base and pointed at apex. Siphonal capsule having inner processes hooked. bifid and outer processes broad. Hemisternite oval to rounded and having stylus which is sparsely setaceous. Spermatheca strongly curved and having infundibulum.

\section{Scymnus nubilus Mulsant (Fig.9-10 and Plate 1 C)}

Very small beetles, oval, elongated and highly pubescent. Head dark brown, eyes black, mouth parts, antennae brown in colour; pronotum dark brown with small spots or patches, scutellum black; elytra dark brown to brown in colour having the black line or patch along commissural line. Elytra heavily pubescent with yellowish hairs. Tegmen with short median lobe, lateral lobes elgonate, slender and sparsely hairy. Apophysis of the $9^{\text {th }}$ abdominal segment expanded broadly at distal end. Sipho strongly curved at base with pointed apex and thread like The inner processes of siphonal capsule is narrow and longer and outer processes is broad and short. Spermatheca curved and finger shaped.

\section{Coccinella septempunctata Linnaeus (Fig.11-13 and Plate 1 D)}

Body medium sized, oval to round in shape. Head black, eyes brown, two yellowish spots present near the margin of eyes, antennae dark brown in colour, pronotum black with two yellow spots laterally; elytra orange in colour, black spots are present on elytra and spots are connected to one another to form a broad black maculae on each elytra in some species. The black pigmented area on elytra extended up to the first spot, leaving only the posterior structural margin of the elytra 
orange coloured. The middle orange areas reduced to crescent shape areas due to the spreading of black pigment from the side of the original third and second spots. Elytra having seven black spots; each elytra having 3 spots and one spot on commissural line of elytra. Maxillary palpi usually large and hatchet shaped. Tarsi pseudotrimerous (or) cryptotetramerous and last tarsal segment elongate and ends with a pair of claws. Siphon short, both inner and outer process of the capsule well developed, apex of siphon with a membraneous expanded bilobed structure. Tegmen short, with internal lobes shorter than the medium lobe. Hemisternite bears a stylus. The hemisternite is elongate, oval; anterior portion of hemisternite bifid and the basal part of hemisternite sparsely hairy. Spermetheca strongly hooked.

\section{Micraspis discolor (Fabricius) (Fig.14-17 and Plate 1 E)}

Females are bright orange in colour and convex dorsally. Males are pale yellowish to orange in colour. Head yellow, compound eyes black; dorsum orange brown; frons sometimes with a black spot. Pronotum pale yellow to yellowish white in colour with black spots or patches towards proximal end. Scutellum black, elytra orange in colour with black commissural line. Pronotum is having half moon shaped black marking at posterior end. Body oval, convex dorsally and glabrous. Antennae eleven segmented, last three segments club shaped and enlarged. In male the last antennal segment is beak shaped. Legs simple, pseudotrimerous or cryptotetramerous and tarsi with apically bifid claw. Tegmen having elongated long lateral lobes with densely hairy, median lobe and the apex of median lobe is pointed. Sipho strongly curved at base, straight at apex. Siphonal capsule well developed, apex of sipho with hooked processes. Spermatheca curved and "C" shaped, the spermatheca attached to the inverted $\mathrm{Y}$ shaped infundibulum.

\section{Brumoides suturalis (Fabricius) (Fig.18-21 and Plate 2 F)}

Head, antennae, pronotum and thorax reddish brown, eyes black; elytra yellowish brown with two longitudinal black stripes on each elytra, legs brown in colour. A median longitudinal black stripe is present which extends from the scutellum to the apex of the elytra. Tegmen with median lobe which is as long as lateral lobes; lateral lobes sparsely having setae and parallel sided. Apophysis of ninth segment broad at base and caudally bifid. Sipho strongly curved with a T-shaped basal part, broadened apically. Siphonal capsule long, quadrate with slender inner process. Spermatheca strongly curved, robust with a W-shaped inner margin.

\section{Illeis cincta (Fabricius) (Fig.22-24 and} Plate 2 G)

Head yellowish; eyes black, antennae pale yellowish, pronotum transparent yellow and scutellum yellowish. Pronotum with a pair of black round spots at posterior end. Elytra grayish yellow to pale yellow and shiny. Elytral commissural line is yellowish. Body is elongate, oval, dorsally convex, wider at middle. Maxillary palpi characteristic, last segment of maxillary palpi enlarged, broad, axe-head shaped. Legs densely hairy, tarsus four segmented and ends with a pair of claws. Tegmen with elongated lateral robes and densely hairy at apex, median lobe longer than lateral lobes. Sipho strongly curved basally. Apex of sipho spatula like and inner processes of siphonal capsule short and round, outer processes pointed. Apophysis of ninth abdominal segment elongated and bifid caudally. Spermatheca considerably long, strongly curved and " $\mathrm{C}$ " shaped. 
Table.1 Predatory Coccinellids collected from pulse crop ecosystems of Chittoor district

\begin{tabular}{|l|l|l|}
\hline Sl. No & Name of the species & \multicolumn{1}{c|}{ Name of the crop } \\
\hline $\mathbf{1}$ & Cheilomenes sexmaculata (Fabricius) & Cowpea, red gram, black gram, green gram \\
\hline $\mathbf{2}$ & Coccinella transversalis Fabricius & Cowpea and black gram \\
\hline $\mathbf{3}$ & Scymnus nubulis Mulsant & Cowpea and black gram \\
\hline $\mathbf{4}$ & Coccinella septumpunctata Linnaeus & Red gram, black gram and cowpea \\
\hline $\mathbf{5}$ & Micraspis discolor (Fabricius) & Black gram \\
\hline $\mathbf{6}$ & Brumoides suturalis (Fabricius) & Green gram and cowpea \\
\hline $\mathbf{7}$ & Illeis cincta (Fabricius) & Cowpea \\
\hline $\mathbf{8}$ & Harmonia octomaculata (Fabricius) & Green gram \\
\hline $\mathbf{9}$ & Jauravia dorsalis (Weise) & Cowpea and green gram \\
\hline $\mathbf{1 0}$ & Pseudospidimerus trinotatus (Thunberg) & Cowpea and red gram \\
\hline
\end{tabular}

Fig.1-4 Chilomenes sexmaculata; 1. Dorsal view of male tegmen, 2. Ventral view of male tegmen, 3. Sipho, 4. Spermatheca; Fig. 5-8: Coccinella transversalis; 5. Dorsal view of male tegmen, 6. Ventral view of male tegmen, 7. Sipho, 8. Spermatheca; Fig.9 - 10: Scymnus nubulis; 9. Sipho, 10. Ventral view of male tegmen; Fig.11-13: Coccinella septumpunctata, 11. Ventral view of male tegmen, 12. Spermatheca, 13. Sipho

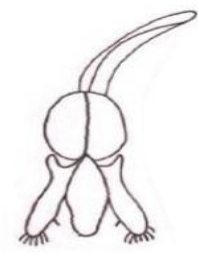

1

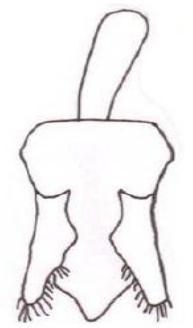

5

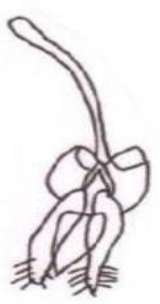

9

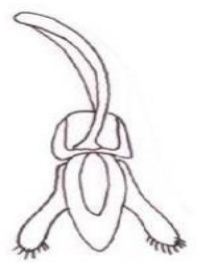

2

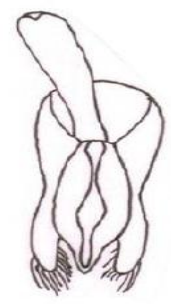

6

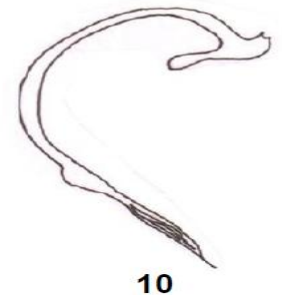

10
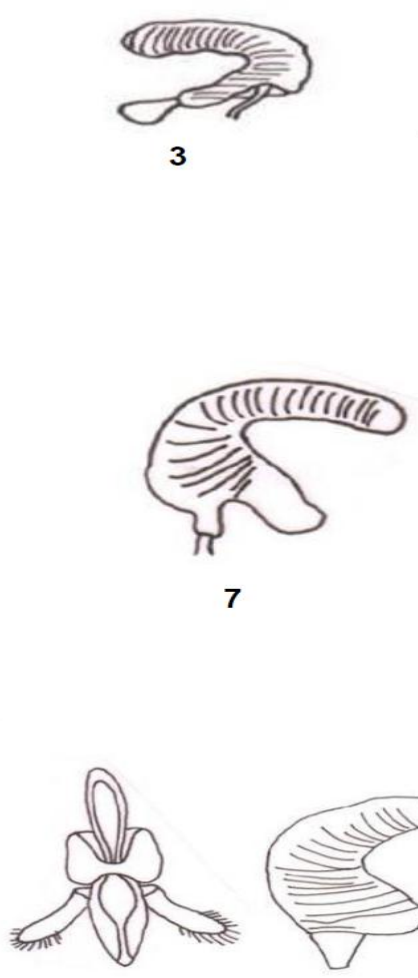

11

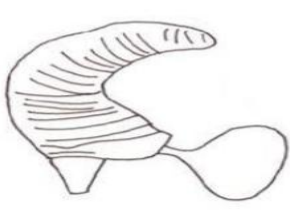

12
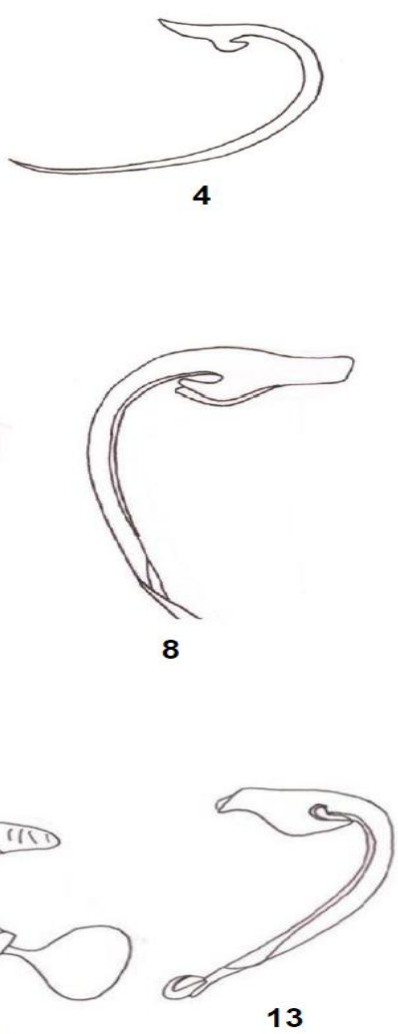
Fig.14-17 Micraspis discolor; 14. Dorsal view of male tegmen, 15. Ventral view of male tegmen, 16. Spermatheca, 17. Sipho; Fig. 18-21: Brumoides suturalis; 18. Dorsal view of male tegmen, 19. Ventral view of male tegmen, 20. Spermatheca 21. Sipho; Fig.22 - 24: Illeis cincta;

21. dorsal view of male tegmen, 22. Ninth abdominal segment of male, 23. Sipho

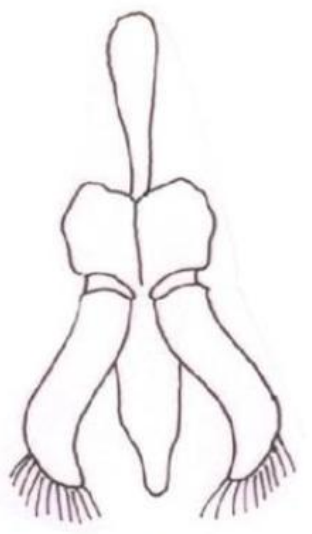

14

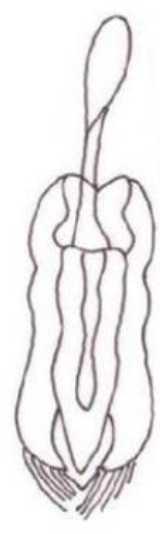

15

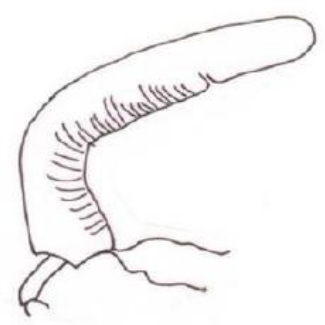

16

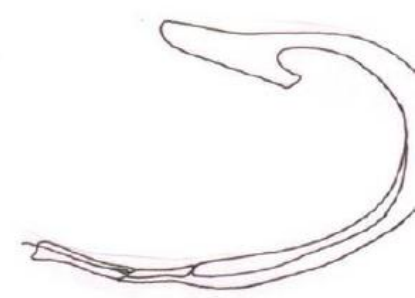

17

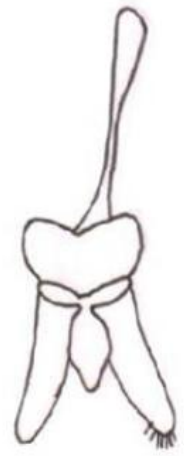

18

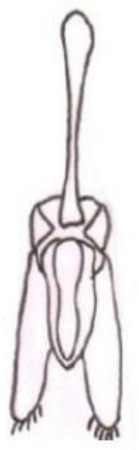

19

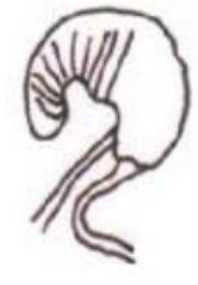

20

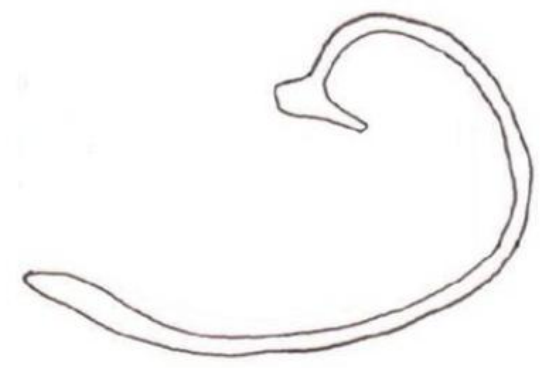

21

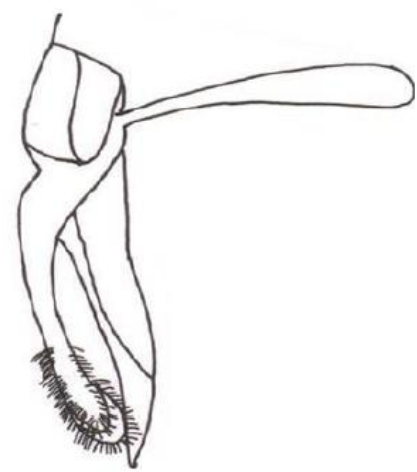

22

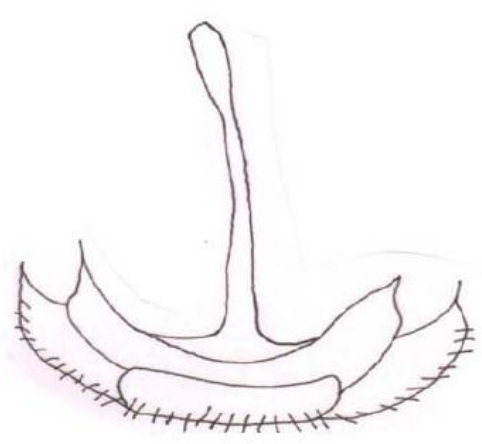

23

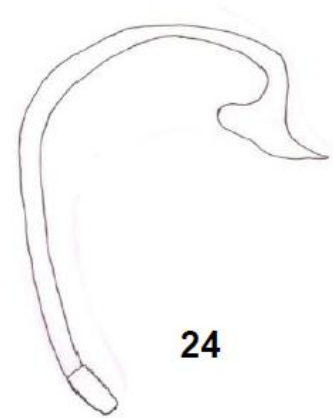


Fig.25-28 Harmonia octomaculata; 25. Dorsal view of male tegmen, 26. Ventral view of male tegmen, 27. Spermatheca, 28. Sipho; Fig. 29-31: Jauravia dorsalis; 29. Dorsal view of male tegmen, 30 Ventral view of male tegmen, 31. Sipho; Fig.32 - 34: Psedospidimerus trinotatus;

32. dorsal view of male tegmen, 33. Ninth abdominal segment of male, 34. Spermatheca

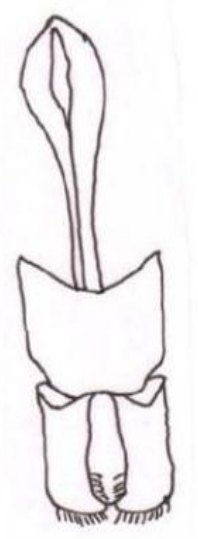

25

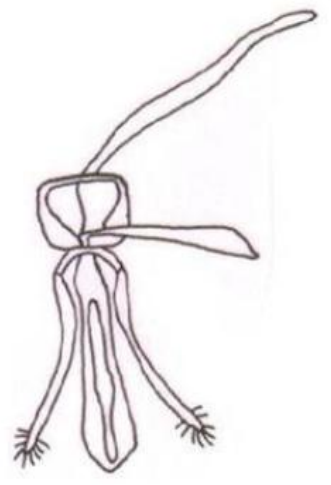

29

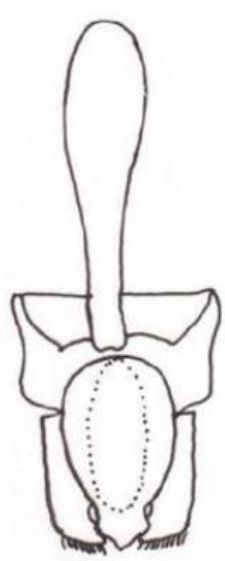

26

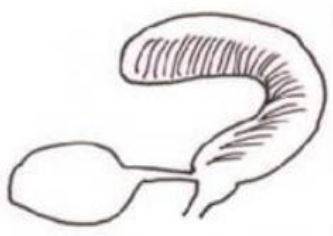

27

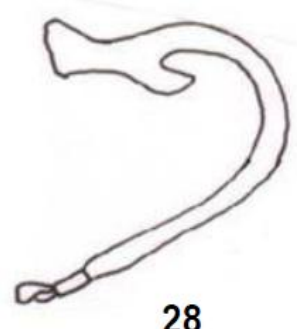

28

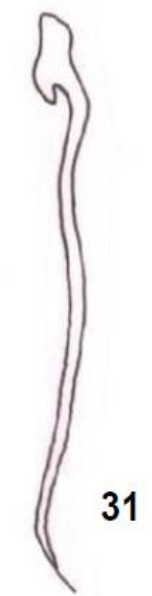

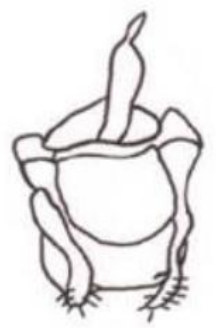

32

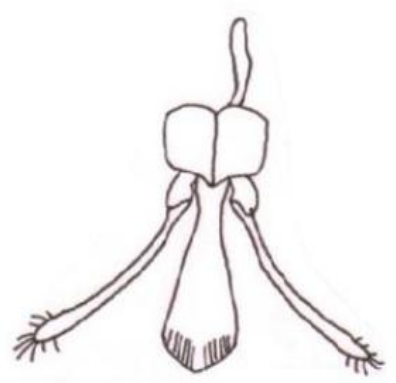

30

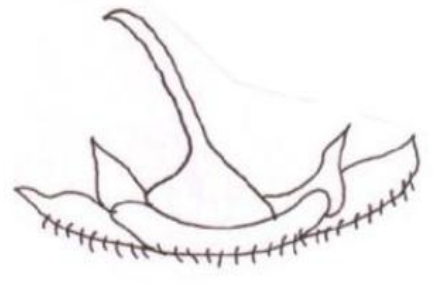

33

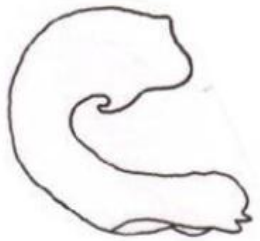

34 
Plate.1 A Chelomenes sexmaculata; B:Coccinella transversalis; C Scymus nubulis; D: Coccinella septumpunctata; E: Micraspis discolor

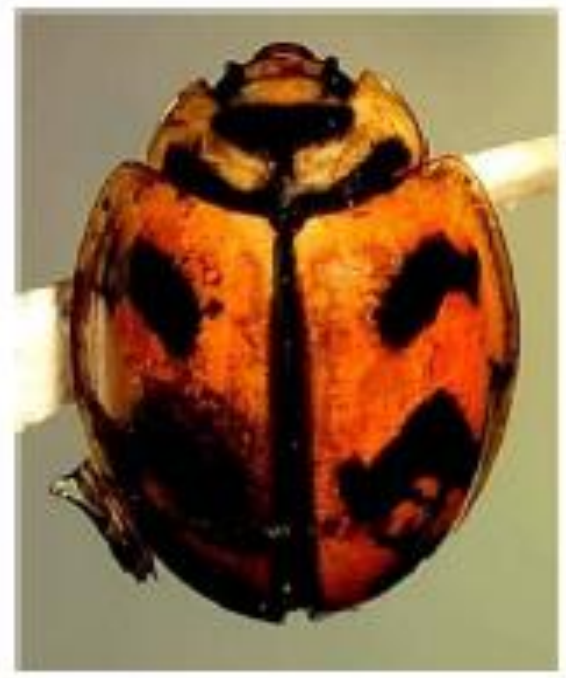

A

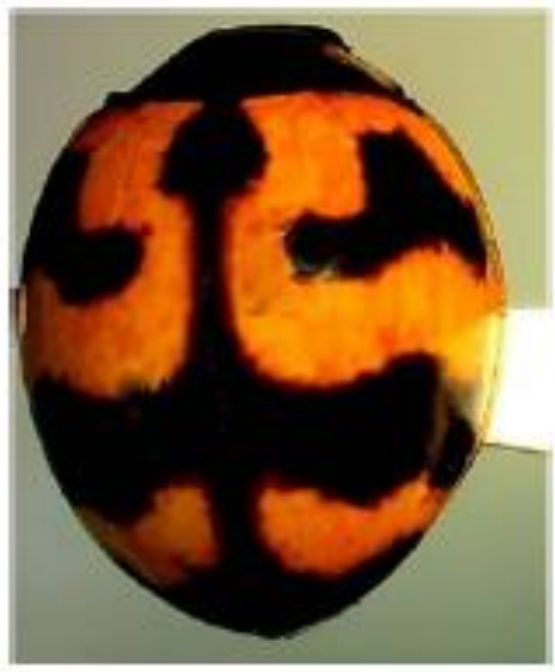

B

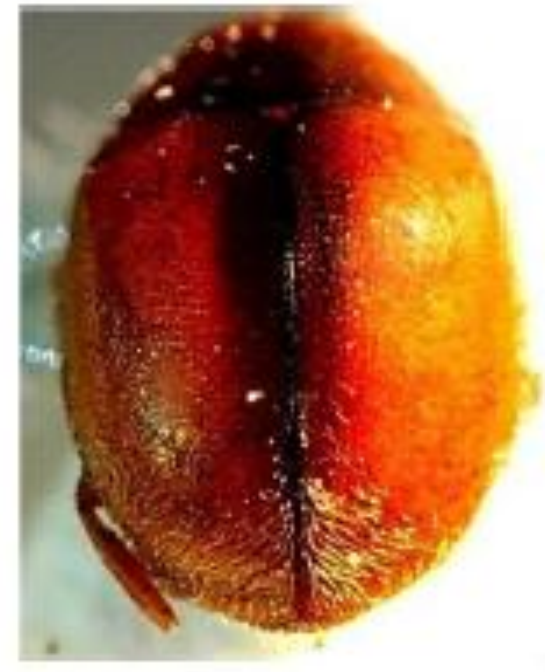

C

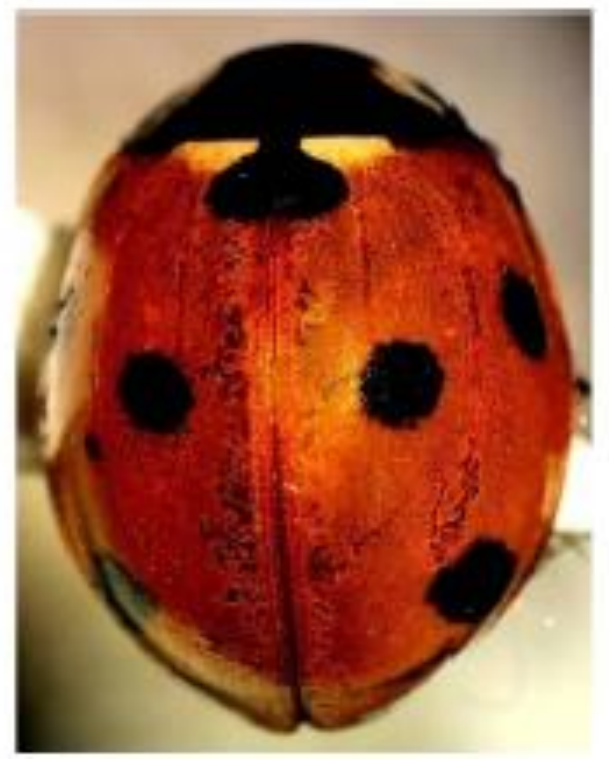

D

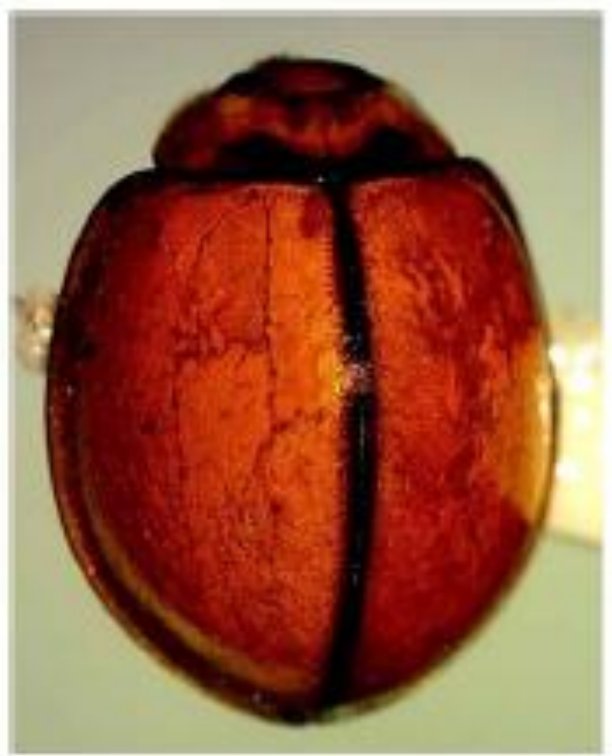

$\mathrm{E}$ 
Plate.2 F: Brumoides suturalis; G: Illeis cincta; H. Harmonia octomaculata; I: Jauravia dorsalis; J: Pseudospidimerus trinotatus

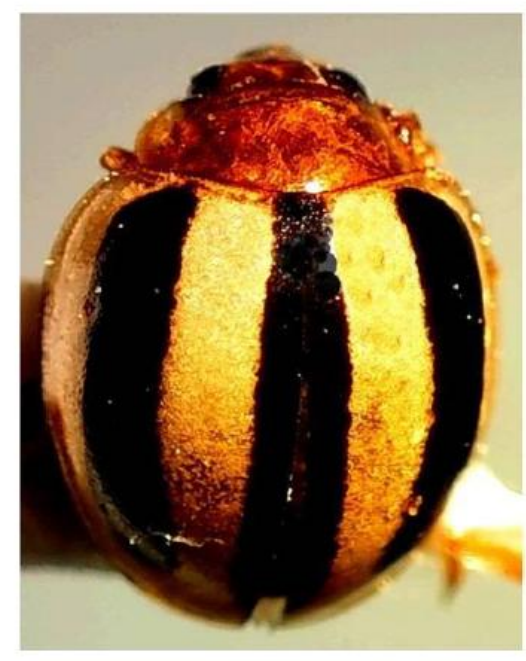

$\mathbf{F}$

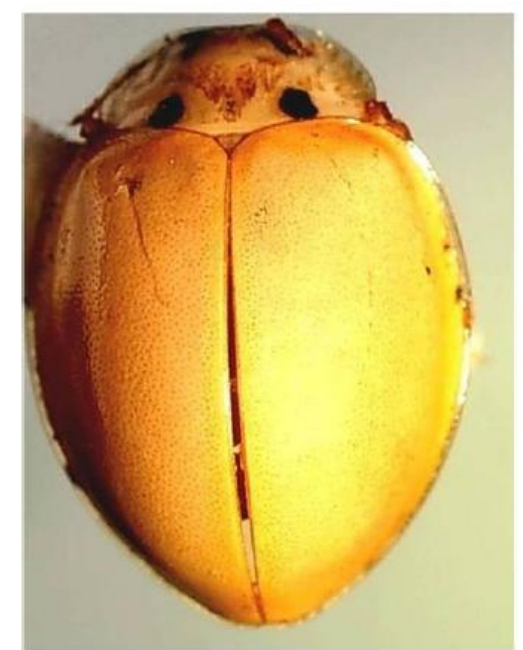

G

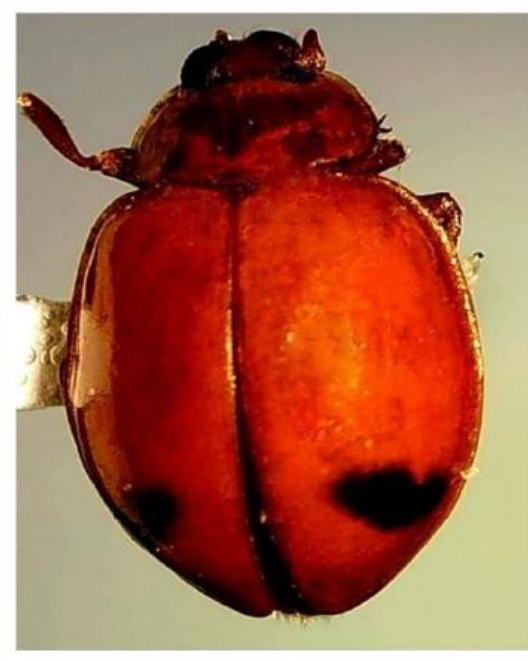

H

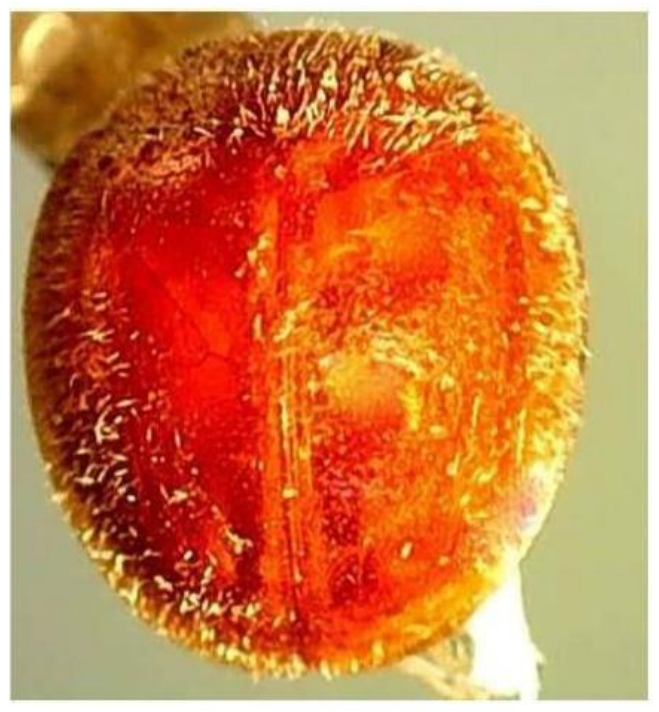

I

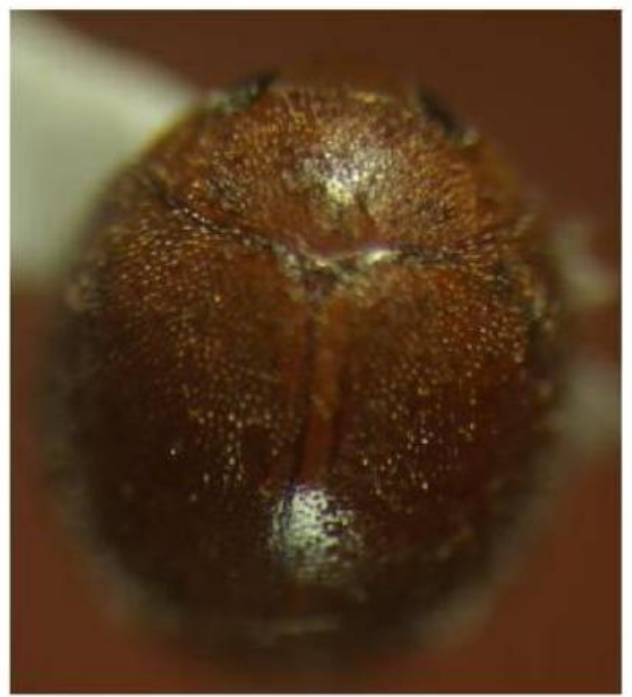

$J$ 


\section{Plate.3 Species composition of Coccinellids in Pulse crop ecosystem}

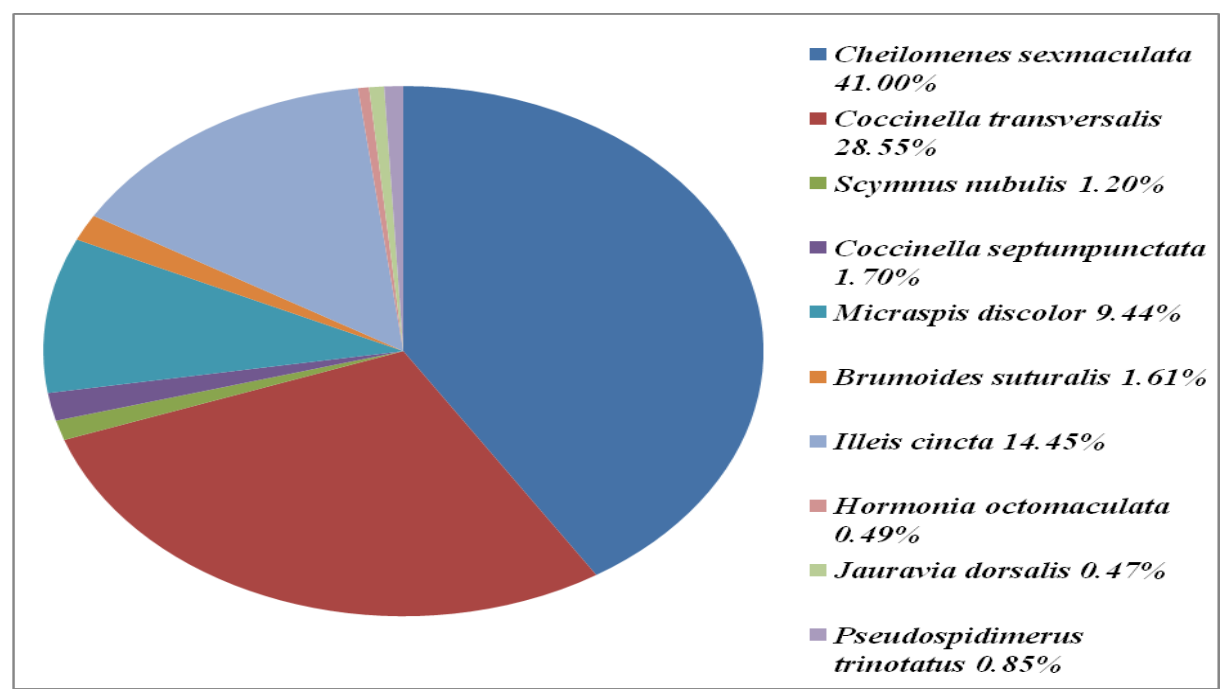

Harmonia octomaculata (Fig.25-28 and Plate 2 H)

Head orange to pale brown with black eyes; antennae and mouth parts reddish brown in colour. Pronotum reddish brown; elytra reddish brown to brown in colour with black maculae on posterior end of elytra. The commissural line of elytra brown in colour. Whitish spots are present on the mesosternum and on the anterior lateral corner of the abdomen. Body oval, longer than broad, dorsally convex and wider at the middle. Antenna eleven segmented, the last segment bulged. Elytra sparsely punctate. Legs simple with four segmented tarsi ending with a pair of claws. Tegmen with short and broad lateral lobes with hairs at apex, median lobe shorter than lateral lobes. Sipho strongly curved at base; straight apically and apex of sipho is spoon shaped with membranous projection. Inner processes of siphonal capsule hooked and outer processes broadened. Spermatheca broadly V-shaped and of uniform width.

\section{Jauravia dorsalis (Weise) (Fig.29-31 and Plate 2 I)}

Body uniformly brownish orange with black compound eyes and mandibles. Body round, pubescent and small. Head coarsely, sparsely, punctuate with one white hair arising from each puncta. Prothorax punctuate, slightly projected anteriorly. Elytra densely punctuate. Siphon nearly straight except at the tip where it is slightly curved outwards, tip pointed; inner process of siphonal capsule curved. Tegmen long, lateral lobes longer than median lobe, lateral lobes pointed, median lobe flattened. A sclerotised spermatheca is absent.

\section{Pseudaspidimerus trinotatus (Thunberg)} (Fig.32-34 and Plate 2 J)

Very small beetles with bright golden yellow to reddish brown colouration. Head brown, eyes black; antennae dark brown in colour, pronotum yellowish, elytra bright yellowish brown. Body oval to round, pubescent and convex. Maxillary palpi barrel shaped, cylindrical with an obliquely truncated apex. In the middle of elytra dark brown spots present. Tarsi 4 segmented with a pair of claws. The median lobe of tegmen very broad and U-shaped, with a medially sinuate posterior margin. The lateral lobes parallel sided and sparsely hairy at their apex. Sipho stout, anteriorly bulbous. 
The key for identification of the Coccinellids associated with pulse crop ecosystems of Rayalseema region of Andhra Pradesh is given here under.

\section{Taxonomic key for identification of Coccinellid predators in Pulse crop ecosystem}

Terminal segment of maxillary palpi strongly divergent apically or nearly parallel sided, mentum usually not very narrowly articulated with submentum. Female genitalia with curved and sac like spermatheca..............................2

-- $\quad$ Body uniformly brownish orange with black compound eyes and terminal segment of maxillary palpi elongate, conical; mentum very narrowly articulated with submentum. Siphon nearly straight except at the tip where it is slightly curved outwards, tip pointed. A sclerotised spermatheca is absent (Fig.29-31 and Plate 2I) Jauravia dorsalis (Sub-family Sticholotinae; Tribe Sticholotini)

2. Body elongate, oval; antennae nine segmented, elytra yellowish brown with two longitudinal black stripes on each elytron. Clypeus strongly expanded laterally. Spermatheca strongly curved, robust with a W-shaped inner margin. Sipho strongly curved with a T-shaped basal part, broadened apically; siphonal capsule long, quadrate with slender inner process (Fig.18-21 and Plate 2F)

\section{suturalis (Fabricius)}

-- Clypeus not strongly expanded laterally; elytral base slightly broader than pronotal base; elytral epipleura narrow, inner carina not reaching elytral apex, elytra without a longitudinal black stripe. Sipho without a $\mathrm{T}$ - shaped basal part, spermatheca curved and finger shaped (Subfa mily Scymninae) 3

3. Eyes usually moderate in size. Head dark brown, mouth parts, antennae brown in colour; antennae nine segmented. Scutellum black in colour, elytra dark brown to brown in colour having a black line or patch along commissural line of elytra and heavily pubescent with yellowish hairs. Sipho strongly curved at base with pointed apex and thread like; the inner processes of siphonal capsule narrow and longer and outer processes broad and short. Spermatheca curved and finger shaped (Fig.9-10 and Plate

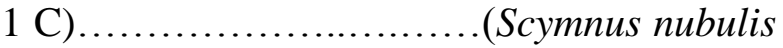
(Subfamily Scymninae Tribe Scymnini)

-- Eyes covered anteriorly by the expanded head capsule; antennae nine segmented and very short, less than onefourth the head width; elytral epipleura very narrow with distinct foveae. Femora broadly expanded concealing the compressed tibiae, tarsi true trimerous; abdomen composed of six segments, of which first segment is convex posteriorly and body medium to small. ..(Tribe

Aspidierini) 4

4. Anterior margin of clypeus with a projection on each side; mandible always with a bifid tip; anterior margin of pronotum usually deeply emarginated and with angulate anterior corners; maxillary galea conical........... Subfamily Coccinellinae Tribe Coccinellini)5

-- Very small beetles with bright golden yellow to reddish brown, head brown, eyes black. Antennae dark brown, pronotum yellowish, elytra bright yellowish brown. Ventral side and legs pale yellowish to dark yellowish in colour. The median lobe of tegmen very broad and U-shaped, with a medially sinuate posterior margin. The lateral lobes parallel sided and sparsely hairy at their 
apex, sipho stout, anteriorly bulbous (Fig.32-

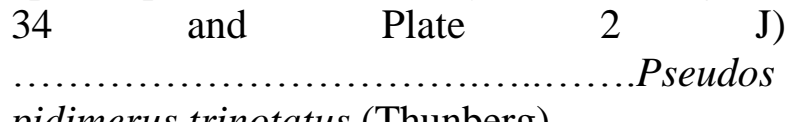

pidimerus trinotatus (Thunberg)

5. Colour variable from creamy orange to bright orange. Pronotum colour yellow to orange with black markings, elytra having the black zigzag markings on each elytra, black spot at posterior end of elytra. Sipho strongly curved at base and thread like apically; the siphonal capsule well developed, the inner processes rounded and external processes pointed. Spermatheca short, stout and curved; in ventral view spermatheca kidney shaped (Fig.1-4 and Plate 1 A) ...................Cheilomenes sexmaculata (Fabricius)

-- Basal segment of antennae elongate and normal; lateral side of elytra margined; inner carina of elytral epipleuron strongly convergent apically or not reaching the apex................................6

6. Anterior margin of mesosternum flat......................................... 7

-- $\quad$ Head orange to pale brown with black eyes. Pronotum reddish brown; elytra reddish brown to brown in colour with black maculae on posterior end of elytra. Whitish spots present on the mesosternum and on the anterior lateral corner of the abdomen. Each elytron with three transverse rows of black spots and an apical spot on a reddish yellow background. Sipho strongly curved at base and straight apically and apex of sipho spoon shaped with membranous projection. Spermatheca broadly V-shaped and of uniform width (Fig.25-28 and Plate 2 $\mathrm{H})$. .Harmonia

octomaculata (Fabricius)

7. Head black, eyes brown, two yellowish spots present near the margin of eyes, pronotum black with two yellow spots laterally; elytra orange in colour, black spots are present on elytra and spots are connected to one another to form a broad black maculae on each elytra. Siphon short, both inner and outer process of the capsule well developed, apex of siphon with a membranous expanded bilobed structure. Spermetheca strongly hooked. (Fig.11-13 and Plate 1 D).............. Coccinella septumpunctata Linnaeus

-- $\quad$ Elytra without three and half round spots and is uniformly coloured........................8

8. Colouration variable; dark yellow, creamy orange, pale yellow or brick red colour, pronotum black with anterior lateral areas orange to yellow. Scutellum black, elytra with black stripes, a large trilobed humeral spot and transverse black stripes. Sipho short and curved at base and pointed at apex. Spermatheca strongly curved and having infundibulum (Fig.5-8 and Plate 1 B)..................Coccinella transversalis Fabricius

-- Elytra without black stripe..................................9

9. Head yellowish; eyes black, antennae pale yellowish, pronotum transparent yellow and scutellum yellowish. Elytra grayish yellow to pale yellow and shiny. Pronotum with a pair of black spots at posterior end. Apex of sipho spatula like and inner processes of siphonal capsule short and round, outer processes pointed. Apophysis of ninth abdominal segment elongated and bifid caudally. Spermatheca considerably long, strongly curved "C" shaped (Fig.22-24 and Plate $2 \mathrm{G})$..............Illies cincta (Fabricius)

-- Elytra orange in colour with black commissural line. Head yellow, compound eyes black. Pronotum pale yellow to 
yellowish white in colour with black spots or patches towards proximal end. Scutellum black, elytra orange in colour with black commissural line. Sipho strongly curved at base, straight at apex; apex of sipho with hooked processes. Spermatheca curved and "C" shaped, the spermatheca is attached to the inverted $\mathrm{Y}$ shaped infundibulum (Fig.14-17 and Plate 1E)............. Micraspis discolor (Fabricius)

\section{Species composition of coccinellids in pulse crop ecosystems}

A total of ten Coccinellid species viz., Cheliomenes sexmaculata, Coccinella transversalis, Coccinella septumpunctata, Illeis cincta, Harmonia octomaculata, Brumoides suturalis, Micraspis discolor, Scymnus nubulis, Jauravia dorsalis and Pseudospidimerus trinotatus were collected from various pulse crop ecosystems viz., red gram, green gram, black gram and cowpea (predominant pulses in Chittoor of Rayalseema region). Among the predatory Coccinellid species recorded, $M$. sexmaculata (41.00\% of total coccinellids) ranked first in abundance followed by $C$. transversalis (28.55\% of total Coccinellids), where as $H$. octomaculata ranked last in abundance (0.49\% of total Coccinellids). The observations were represented in pie chart (Plate 3).

Puttarudriah and Channabasavanna (1953, $1955,1956)$ has reported five species of coccinellids on groundnut crop viz., Coccinella septempunctata Linnaeus, Coccinella transversalis Fabricius, Harmonia octomaculata (Fabricius), Micraspis discolor (Fabricius) and Cheilomenes sexmaculata (Fabricius). Joshi and Sharma (2008) reported Brumoides suturalis feeding on aphid, Aphis gossypii Glover from Black Gram. Khan et al., (2008) reported B. suturalis feeding on Aphis craacivora Koch and A. gossypii from pulse crop ecosystems. Chanmamla (2009) reported three species viz., Coccinella septempunctata Linnaeus, Coccinella transversalis Fabricius, Harmonia octomaculata (Fabricius), from groundnut and cow pea crop ecosystem feeding on aphids, $A$. craccivora and leafhoppers, Empoasca (Empoasca) motti Pruthi. Among these species, Coccinella transversalis Fabricius is abundant recording $52 \%$ of population followed by Cheilomenes sexmaculata (Fabricius) (29\%). Rekha et al., (2009) has reported three species of Coccinellids viz., Coccinella transversalis, Menochilus sexmaculatus and Brumoides suturalis from pulses crop ecosystems. Rani et al., (2013) has reported, Cheilomenes sexmaculata as predominant Coccinellid species in Khammam district of Andhra Pradesh from green gram gram crop ecosystems. Chaudary et al., (2015) reported B. suturalis from IndoBangladesh border in rice crop ecosystem. Ponnuswamy (2018) reported B. suturalis from rice, chilli crop ecosystems, $C$. septumpunctata from rice crop ecosystem, $H$. octomaculata on wheat crop ecosystem and $c$. sexmaculata from cow pea crop ecosystem from West Bengal. An illustrated key along with diagnostic taxonomic characters, colour photographs of these Coccinellids were provided for easy identification of the Coccinellids. These Coccinellid species acts as main predators in different crop ecosystems and studies on species composition and identification of Coccinellid species occurring in any crop ecosystem is highly essential in order to utilize these Coccinellids in biological control programme.

\section{References}

Chanmamla, G. 2009. Taxonomic studies on predacious coccinellidae, order: Coleoptera. M.Sc. (Ag) Thesis. Acharya N. G. Ranga Agricultural University, Andhra Pradesh, India. 
Chaudary, S., Pritin, P., Sontakke, T., Boopathi, T., Bhattacharjee, J., Bhattacharjee, D and Malsawmzuali. 2015. Taxonomic studies on predatory Coccinellid beetles and other species composition in rice ecosystem of IndoBangladesh border. The Bioscan. 10(1): 229-242.

Joshi, P. C and Sharma, P. K. 2008. First Records of Coccinellid Beetles (Coccinellidae) from the Haridwar, (Uttarakhand), India. The Natural History Journal of Chulalongkorn University 8(2): 157-167.

Khan, M. R., Irshad, M and Rafi, M. A. 2008. Insect fauna of Azad Jamm and Kashmir. M K Traders, Islamabad. pp: 143.

Kundoo, A. A and Khan, A. A. 2017. Coccinellids as biological control agents of soft bodied insects: A review. Journal of Entomology and Zoology Studies. 5(5): 1362-1373.

Megha, R. R., Vastrad, A. S., Kamana, B. C and Kulkarni. N. S. 2015. Species complex of Coccinellids in different crops at Dharwad region. Journal of Experimental Zoology. 18(2): 931935.

Omkar and Pervez, A. 2004. Predaceous coccinellids in India: Predator-prey catalogue (Coleoptera: Coccinellidae). Oriental Insects. 38: 27-61.

Pajni, H. R and Verma, S. 1985. Studies on the structure of the male genetalia in some Indian Coccinellidae (Coleoptera). Research Bulletin of the Punjab University. 36: 195-201.

Ponnuswamy, N. 2018. Taxonomical And Bioecological Studies On Predaceous Coccinellid Beetles Associated With Various Crop Ecosystems. M. Sc. (Ag.) Thesis submitted to Uttara Bangla Krishi Vidyalaya.

Poorani J. 2002 An annotated checklist of the
Coccinellidae (Coleoptera) (excluding Epilachninae) of the Indian sub region. Oriental Insects. 36: 307-383.

Puttarudraiah, M and Channabasavanna, G. P. 1953. Beneficial Coccinellids of Mysore I. Indian Journal of Entomology. 15: 87-96.

Puttarudraiah, M and Channabasavanna, G. P. 1955. Beneficial Coccinellids of Mysore II. Indian Journal of Entomology. 17: 1-5.

Puttarudraiah, M and Channabasavanna, G. P. 1956. Some Beneficial Coccinellids of Mysore III. Journal of Bombay National History Society. 54: 156-159.

Rani, C. H., Rao, G. R., Chalam, M. S. V., Kumar, P. A and Rao, V. S. 2013. Summer season survey for incidence of Maruca vitrata (G.) (Pyralidae: Lepidoptera) and its natural enemies on green gram and other alternative hosts in main pulse growing tracts of Khammam district. Journal of Research, ANGRAU. 41(3): 16-20.

Rekha, B. S., Kumar, J. R., Kandibane, K., Raguraman, S and Swamiappan, M. 2009. Diversity of coccinellids in cereals, pulses, vegetables and in weeded and partially weeded ricecowpea ecosystems in Madurai district of Tamil Nadu. Madras Agricultural Journal. 96(1-6): 251-264.

Sasaji, H. 1968. Phylogeny of the family Coccinellidae (Coleoptera). Etizenia Fukui. 35: 1-37

Slipinski A and Tomaszewska W. 2005 Revision of the Oriental Coccinellidae (Coleoptera). Australian Journal of Entomology. 44(1): 369-384.

Vandenberg N, J. 2000 Coccinellidae Latreille. In: Arnett RH, Thomas, MC and Skelley PE, (editors) American Beetles, Polyphaga: Scarabaeoidea through Curculionoidea. 2: 371-389. 
How to cite this article:

Vasista, T., M. S. V. Chalam, K. V. Hariprasad and Mohan Naidu, G. 2020. Coccinellid Funa Associated with Pulse Crop-ecosystems from Rayalseema Region of Andhra Pradesh. Int.J.Curr.Microbiol.App.Sci. 9(08): 865-879. doi: https://doi.org/10.20546/ijcmas.2020.908.094 